\title{
THE HISTORICAL DENDROARCHAEOLOGY OF TWO LOG STRUCTURES AT THE MARBLE SPRINGS HISTORIC SITE, KNOX COUNTY, TENNESSEE, U.S.A.
}

\author{
JESSICA D. SLAYTON ${ }^{1}$, MAGGIE R. STEVENS ${ }^{1}$, HENRI D. GRISSINO-MAYER ${ }^{1 *}$, and CHARLES H. FAULKNER ${ }^{2}$ \\ ${ }^{1}$ Laboratory of Tree-Ring Science, Department of Geography, The University of Tennessee, Knoxville, \\ Tennessee 37996, USA \\ ${ }^{2}$ Department of Anthropology, The University of Tennessee, Knoxville, Tennessee 37996, USA
}

\begin{abstract}
The Marble Springs homestead in south Knox County serves as a significant heritage site for the state of Tennessee because it was the final home of one of our nation's most important founding statesmen and first governor of Tennessee (1796 to 1801, 1803 to 1809), John Sevier. Recent archaeological and historical research had called into question the authenticity of the original John Sevier log cabin located at the Marble Springs homestead. We used tree-ring dating to determine the year(s) of construction of the Governor John Sevier cabin and the adjacent Walker Springs log cabin (which had been relocated to the site later and has no ties to Gov. John Sevier) by first extracting cores from all accessible logs in the cabins and then evaluating the cutting dates of these logs. A nearby reference chronology at Norris Dam anchored the Gov. John Sevier cabin chronology from 1720 to 1834 and the Walker Springs cabin chronology from 1675 to 1826 . The cutting dates obtained from six logs in the Gov. John Sevier cabin suggest construction of the cabin was completed sometime between late 1835 and early 1836. We were able to date cores from 29 logs from the Walker Springs cabin, which strongly support final construction between late 1827 to early 1828 . Our dendrochronological analyses suggest that the cabin at Marble Springs long thought to be the original cabin occupied by Gov. John Sevier was instead likely built during the occupancy of the property by a later tenant, George Kirby, in the early to mid-1830s, well after the death of Sevier in 1815.
\end{abstract}

Keywords: Tree rings, historical dendroarchaeology, Governor John Sevier, Marble Springs, Tennessee.

\section{INTRODUCTION}

The study of dendroarchaeology uses treering dating techniques to determine when a tree was harvested in order to derive the year or years of construction for a structure composed of wood or with wood incorporated (Bannister 1962; Dean 1978). The information from this type of analysis allows agencies charged with the care of historical structures to authenticate the historical significance and authenticity of a structure. These treering dating techniques are increasingly being used in the Southeastern U.S. to date the construction of historic structures (Bowers and Grashot 1976; Stahle 1979; Bortolot et al. 2001; Mann 2002;

*Corresponding author: grissino@utk.edu; Fax 865974-6025; Telephone 865-974-6029
Reding 2002; Wight and Grissino-Mayer 2004; Lewis et al. 2006; Grissino-Mayer and van de Gevel 2007). Such structures can be accurately dated with existing reference tree-ring chronologies that have been developed previously in the Southeast and housed in the International TreeRing Data Bank at the National Climatic Data Center in Asheville, North Carolina. In some cases, these studies have proven that accepted construction dates based on documentary evidence and oral tradition are inaccurate (Mann 2002; Grissino-Mayer and van de Gevel 2007).

The tree-ring records from such structures are also valuable for extending existing chronologies further back in time to the $16^{\text {th }}$ and $17^{\text {th }}$ Centuries or perhaps earlier. This is accomplished by crossdating where matching, overlapping patterns of 


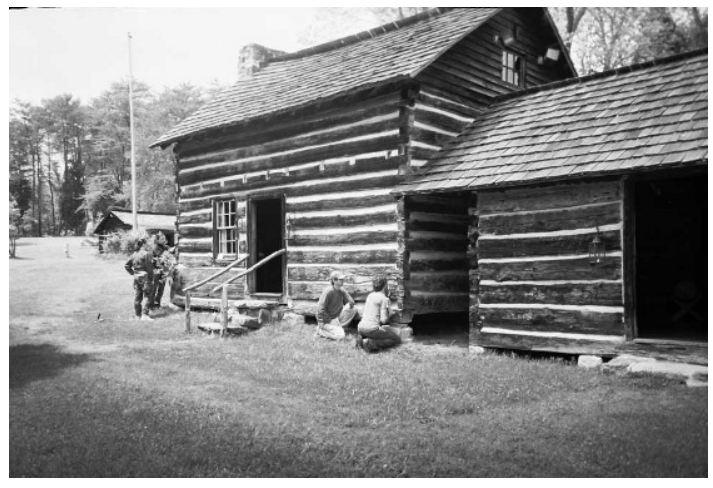

Figure 1. The Governor John Sevier cabin (larger structure on the left), showing the doorway on the south entrance. The reconstructed kitchen is located to the right, separated from the main cabin by a narrow covered walkway.

narrow and wide rings from living trees are compared against progressively older pieces of wood (Fritts 1976; Baillie 1982). The unique temporal patterns of wide and narrow rings are essential for crossdating the samples of wood. The variability in ring widths is caused by changes in regional climate on a year-to-year basis so that the patterns are recorded in a similar pattern in the ring widths (Fritts 1976). Other sets of tree rings can then be dated by comparing them to the established reference chronology.

The cabin located at the Marble Springs Historic Site (Figure 1) is believed to have been the home of Tennessee's first governor, John Sevier (b. 1745, d. 1815). Sevier was the first and only governor of the short-lived State of Franklin (1785-1788), served as brigadier general of militia for the Washington District of the Territory South of the River Ohio (as Tennessee was known then), and then served as governor of Tennessee from 1796 to 1801, and again from 1803 to 1809 . Governor John Sevier is thought to have acquired the Marble Springs property via a North Carolina land grant sometime around 1796 when he began to live there part-time. He named the site "Marble Springs" for the two year-round flowing springs on the property (Miller 2000; Barber 2005). Over the years, several buildings were located at the site, including the main cabin attached to a kitchen by a dogtrot (a covered passageway), a springhouse, a barn and crib, an ash hopper, a smokehouse, and four or five other cabins. Sevier himself is believed to have made improvements to structures on the site during the years he spent at Marble Springs (Sevier 1790-1815).

Local lore has recently questioned the legitimacy of the main structure at the Marble Springs homestead dating to the period of occupancy by Governor John Sevier. Although archaeological testing around the John Sevier cabin produced numerous artifacts that dated to the late 1700s, the cabin has been subject to "...a persistent rumor that the present building was not his [John Sevier's] home at Marble Springs" (Faberson and Faulkner 2005). Sevier himself never mentioned building the cabin (Barber 2005) and, for someone of Sevier's national stature, the cabin is rather small and simplistic, even by the standards of 1800. Furthermore, Ramsey's famous 1853 description of the "secluded spot" where "stood the cabin of Governor Sevier" (Ramsey 1853, p. 710) is actually describing a location far from the current Marble Springs homestead (Faberson and Faulkner 2005).

To help settle this controversy, our goal was to determine the year(s) of construction for Gov. John Sevier's cabin at the Marble Springs homestead to verify whether or not this cabin could indeed have been the home of Governor John Sevier. We used a well-established reference treering chronology that exists for the east Tennessee region to date the Gov. John Sevier cabin, but also took advantage of the tree-ring record in the wellpreserved oak logs found in another cabin located on the Marble Springs property. Called the Walker Springs cabin (Figure 2), this two-story structure was originally located in the western area of the city of Knoxville, Tennessee, near Walker Springs Road (Faulkner 1991). It was moved to its current location at Marble Springs in March 1987 and has no ties whatsoever to Gov. John Sevier. The logs in this cabin consist of oak timbers exclusively, many containing well over 100 tree rings.

\section{METHODS}

\section{Field Methods}

We extracted 0.5 " diameter cores from oak and pine logs in the Gov. John Sevier cabin with a 


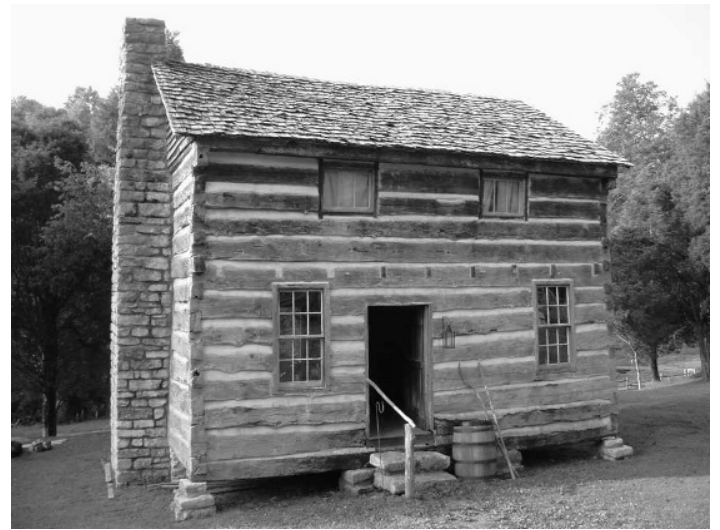

Figure 2. The two-story Walker Springs cabin sits near the Governor John Sevier cabin, but was relocated to the Marble Springs Historic Site in 1987. View is of the north side. Note the differences in log sizes and their state of preservation in this cabin with logs in the Governor John Sevier cabin (Figure 1).

specially designed hollow, cylindrical drill bit attached to a hand drill (Figure 3). To assist the crossdating process, we also cored logs from all four walls and both levels of the Walker Springs cabin. Sample identifications were assigned to the cores, which consisted of an abbreviation for the building ("JS" or "WS"), the cardinal direction of orientation of the wall $(\mathrm{N}, \mathrm{S}, \mathrm{E}$, or $\mathrm{W})$, the $\log$ number (beginning with the bottom $\log =$ " 01 "), and sequential letters for each core extracted from the $\log (\mathrm{A}$ through D). Each side of the cabin was sketched and all sampled locations indicated on the sketch.

Whenever possible, each log was sampled both at the basal (bottom location on the tree trunk) and distal (upper location of the tree trunk) ends at a location with a smooth, intact, curved surface where the outermost rings were most likely to be preserved. At least two cores per log were taken to minimize the expected effects of intra-ring variability and also for replication should internal defects occur in one of the cores. Before coring, the outer surface of the target area was marked with permanent ink to verify that the outer rings had remained intact after coring. An appropriate angle and depth for coring was estimated by examining the end of the log and locating the tree pith. After the appropriate depth was reached, the core was extracted by dislodging the attached end of the core with a hooked, thin steel rod designed

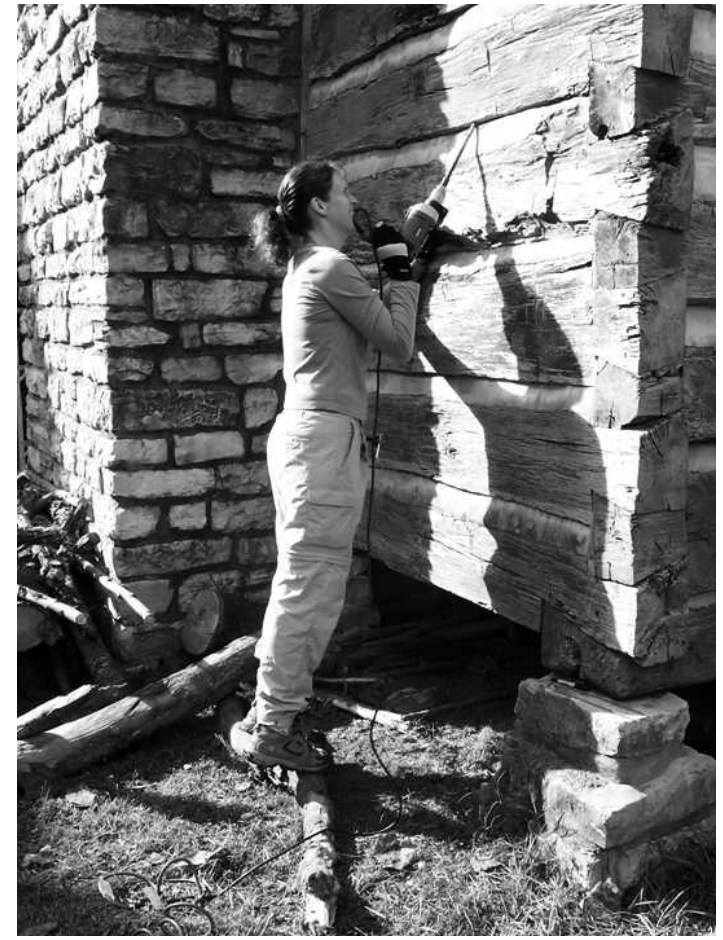

Figure 3. Extracting a core from the Walker Springs cabin (east side, log WSE04, basal end) using an electric drill and the specially-designed hollow corer.

for that purpose. The extracted cores were then immediately glued onto wooden core mounts with the cells aligned vertically so that the wood surface could be sanded on a transverse plane. All relevant information about each sample was written on the core mount.

\section{Laboratory Methods}

The cores were sanded using progressively finer sandpaper, beginning with ISO P40-grit $(425-500 \mu \mathrm{m})$ and ending with ANSI 400-grit (20.6-36.0 $\mu \mathrm{m}$ ) (Orvis and Grissino-Mayer 2002). The sanding process produced a surface on the wood that allowed the cellular structure of the tree rings to be visible under standard $10 \times$ magnification. All tree rings on each core were then marked by decades starting from the innermost complete ring (complete earlywood and latewood = ring number "1") to help with the measuring and crossdating procedures. Each 10th ring was marked with a single dot, every 50th ring with 
two dots, and every hundredth ring with three dots (Stokes and Smiley 1968). The ring widths of each core were then measured to the nearest $0.001 \mathrm{~mm}$ using a Velmex measuring system and Measure J2X software. The measurement files created by this process were used for statistical crossdating.

\section{Crossdating}

The ring-width measurements for each core were then statistically crossdated to reference treering chronologies that already existed within the region. Reference chronologies were obtained from the International Tree-Ring Data Bank (IGBP PAGES/World Data Center for Paleoclimatology) in Asheville, North Carolina. We used the Norris Dam State Park (1633 to 1980) and Piney Creek Pocket Wilderness (1651 to 1982) reference chronologies (both white oak, Quercus alba L.) from eastern Tennessee to anchor the measurement series from the two structures in time (Duvick 1981, 1983). Of these two chronologies, the Norris Dam chronology proved the most useful. The chronology consists of 71 dated series with an excellent average inter-series correlation of 0.61 and an average mean sensitivity of 0.20 .

The undated measurements were compared one at a time to these reference chronologies using the computer program COFECHA (Holmes 1983; Grissino-Mayer 2001). COFECHA first removes age-related and other low-frequency trends through a three-step iterative process to ensure the year-to-year (i.e. high-frequency) trends are emphasized as these are necessary for successful crossdating. COFECHA then uses segmented time-series correlation techniques to crossdate the undated series against the reference chronologies. We tested 40-year segments of each measurement series lagged 20 years. Correlation coefficients were calculated for each segment as a measure of the strength of the relationship of that segment with other 40-year segments throughout the reference chronologies. For an undated series to be considered dated, the temporal placements suggested by COFECHA had to be systematic for all or most of the tested 40-year segments, i.e. most segments had to have the same date adjustment (such as " +1727 "). The correlation coefficients also had to be statistically significant $(\mathrm{r} \geq 0.37, \mathrm{p}<0.01)$, although some erratic ring patterns caused the correlations for certain segments to fall below this critical threshold, which is common in dendrochronology, especially for eastern tree species. Notable marker rings were then identified and recorded to assist in the crossdating of other series via the list method (Phipps 1985; Yamaguchi 1991) and using scatter plots. The final placement of a series in time had to be both visually and statistically convincing (Grissino-Mayer 2001).

Once dated against the reference chronologies, all series were combined into one measurement file and again tested using COFECHA to ensure crossdating accuracy internally among the series. COFECHA flagged low correlations $(r<$ $0.37, \mathrm{p}>0.01)$ that required re-inspection. If the alternate position suggested by COFECHA was unrealistic (for example, a " +9 " adjustment when both 40-year segments on either side were dated correctly) or displayed a statistically significant correlation, the segment was kept at its original placement. Series that did not crossdate convincingly against either of the reference chronologies or with the crossdated individual series were temporarily put aside. We later attempted to crossdate them with the final crossdated tree-ring chronology created from each cabin.

Two statistical descriptors were used to assess the quality of the crossdating. First, the average inter-series correlation calculated by COFECHA is an average of the correlation coefficients for each measurement series when correlated against the master chronology created from all the other dated series (Grissino-Mayer 2001). In general, an inter-series correlation of 0.40 or higher is desirable for consideration as a correctly dated series. Second, we used the average mean sensitivity, a measure of year-to-year variability, for all dated series. Because crossdating is a highfrequency process, high mean sensitivities (generally above 0.20 for southeastern tree species) facilitate the crossdating process. Low mean sensitivities result when the tree-ring series exhibit very little year-to-year variability. This lower amount of variability, known as complacency, 
occurs when trees experience little environmental stress. Mean sensitivity values around 0.20 are common for oak tree-ring patterns from the southeastern U.S. (DeWitt and Ames 1978).

\section{Establishing Cutting Dates for Logs}

We examined the outermost dated ring on each core at high magnification and then assigned a symbol to determine the likely period of cutting (Bannister 1962; Nash 1999):

B: bark is present, indicating the outer ring is fully intact (certainly a cutting date);

$r$ : outermost ring is continuous and intact around a smooth surface, but no bark is present (considered a cutting date);

$\mathrm{v}$ : the date is within a few years of the cutting date, based on presence of sapwood;

vv: impossible to determine how far the outer ring is from the true outer surface (no sapwood present and rings in the heartwood are likely missing).

++ : a ring count was necessary for the outermost core section on a core with two sections separated by decay.

We carefully inspected the completeness of the outermost ring by looking for complete formation of earlywood vessels in the oaks followed by complete formation of latewood with no earlywood vessels formed in the following year. The latewood and earlywood of prior rings guided us in assessing whether the outermost ring appeared completely formed. If a ring was completely formed, the tree was most likely cut during the tree's dormant period after that year, a period spanning several months from the fall of one calendar year to the spring of the next. Because of the possibility of the tree having been cut in either of the two years in the cases of fullyformed outer rings, we assigned the cutting date based on the year of the complete outer ring, although the tree may have been cut the following year before growth resumed.

Cores taken from dry seasoned wood are often brittle and the sapwood can be decayed considerably or riddled with insect galleries, causing the cores to be in two or more sections.
Table 1. Statistics for oak cores from the Governor John Sevier Cabin.

\begin{tabular}{lcccc}
\hline Series & $\begin{array}{c}\text { Begin } \\
\text { Year }\end{array}$ & $\begin{array}{c}\text { End } \\
\text { Year * }\end{array}$ & $\begin{array}{c}\text { Inter-series } \\
\text { Correlation }\end{array}$ & $\begin{array}{c}\text { Mean } \\
\text { Sensitivity }\end{array}$ \\
\hline JSE01A & 1739 & 1812 & 0.42 & 0.18 \\
JSE01B & 1718 & 1813 & 0.40 & 0.24 \\
JSE01C & 1734 & 1813 & 0.65 & 0.22 \\
JSN03B & 1740 & 1804 & 0.81 & 0.27 \\
JSN03C & 1738 & 1833 & 0.70 & 0.23 \\
JSN03D & 1744 & 1814 & 0.77 & 0.23 \\
JSN09C & 1766 & 1817 & 0.45 & 0.18 \\
JSN09D & 1759 & 1820 & 0.52 & 0.18 \\
JSS01A & 1723 & 1814 & 0.73 & 0.23 \\
JSS01B & 1745 & 1829 & 0.47 & 0.20 \\
JSS03A & 1746 & 1833 & 0.70 & 0.18 \\
JSS03B & 1725 & 1834 & 0.70 & 0.26 \\
JSS03D & 1751 & 1834 & 0.67 & 0.19 \\
JSS03E & 1747 & 1818 & 0.60 & 0.25 \\
JSW04B & 1740 & 1832 & 0.81 & 0.19 \\
JSW04C & 1747 & 1833 & 0.79 & 0.20 \\
& Average & 0.64 & 0.22 \\
\hline
\end{tabular}

*"End Year" represents the last measurable ring on the series. Many cores had additional rings on small detached segments that could be counted and added to obtain a more accurate harvest date.

We crossdated the rings on each core up to the gap, and then counted the number of rings in the outermost detached section of the core (which included the outermost ring and therefore the cutting date of the $\log$ ) and added this ring number to the outermost crossdated ring on the innermost core section. For these cores, the outermost date was a terminus post quem, i.e. a year after which the log had been harvested for inclusion in the structure (Baillie 1995).

\section{RESULTS}

We extracted 31 cores from 11 oak logs and 7 cores from 5 pine logs in the John Sevier cabin, while 53 cores representing 31 oak logs were extracted from the Walker Springs cabin. The final oak chronology for the John Sevier cabin consisted of 16 oak cores representing 6 logs (Table 1). Although some crossdating was evident for the pine cores when compared to the oak reference chronologies, the matches were not conclusive enough to warrant assigning exact calendar years. For the Walker Springs log cabin, 48 cores were 
used to develop the final tree-ring chronology, representing 29 logs (Table 2).

\section{Descriptive Statistics}

For the John Sevier cabin oak chronology, the average inter-series correlation was 0.64 (Table 1), and 0.61 for the Walker Springs cabin (Table 2). The values for the oak chronologies are well above the minimum 0.40 we prefer to see as a sign of the quality of internal crossdating for a set of site measurements. Both values are also comparable to the average inter-series correlations for the Norris Dam and Piney Creek reference chronologies ( 0.61 and 0.58 , respectively). For the John Sevier cores, the average mean sensitivity was 0.22 (Table 1). For cores from the Walker Springs cabin, the average mean sensitivity was also 0.22 (Table 2). The values for the oak chronologies are higher than the average reported for 16 other white oak chronologies in the eastern and central U.S. (average $=0.16$, with upper 95\% confidence limit of 0.20, DeWitt and Ames 1978), and are slightly higher than the values for the reference tree-ring chronologies used to crossdate our series (Norris Dam $=0.20$, Piney Creek $=$ $0.20)$.

\section{Crossdating}

For the 16 cores from the John Sevier cabin, COFECHA tested 61 40-yr segments for crossdating accuracy and flagged only five (8.2\%) as possibly being misdated. Four of these flags occurred on the two cores from one tree, JSN09 (Table 3), although the overall inter-series correlations for these two cores were acceptable (JSN09C $=0.45$ and JSN09D $=0.52)$. For the 48 cores from the Walker Springs cabin, COFECHA tested 244 40-year segments and flagged only seven $(2.9 \%)$ as being possibly misdated. The rings in all 12 flagged segments for both structures were inspected and found to be correctly placed in time. Rather than being possibly misdated, these segments contained erratic rings or ring patterns (e.g. the extremely wide ring for 1816 on core JSN09C) that significantly lowered the correlations for these ring segments. These erratic
Table 2. Statistics for oak cores from the Walker Springs Cabin

\begin{tabular}{|c|c|c|c|c|}
\hline Series & $\begin{array}{l}\text { Begin } \\
\text { Year }\end{array}$ & $\begin{array}{l}\text { End } \\
\text { Year }\end{array}$ & $\begin{array}{l}\text { Inter-series } \\
\text { Correlation }\end{array}$ & $\begin{array}{c}\text { Mean } \\
\text { Sensitivity }\end{array}$ \\
\hline WSE01A & 1728 & 1823 & 0.56 & 0.20 \\
\hline WSE01B & 1719 & 1800 & 0.56 & 0.19 \\
\hline WSE02A & 1739 & 1821 & 0.59 & 0.24 \\
\hline WSE02B & 1747 & 1814 & 0.66 & 0.28 \\
\hline WSE03A & 1721 & 1826 & 0.51 & 0.14 \\
\hline WSE03B & 1694 & 1793 & 0.70 & 0.20 \\
\hline WSE05A & 1726 & 1800 & 0.71 & 0.19 \\
\hline WSE05B & 1717 & 1826 & 0.64 & 0.21 \\
\hline WSE11A & 1699 & 1819 & 0.61 & 0.22 \\
\hline WSN02A & 1714 & 1819 & 0.66 & 0.29 \\
\hline WSN03A & 1754 & 1826 & 0.58 & 0.21 \\
\hline WSN03B & 1774 & 1826 & 0.73 & 0.20 \\
\hline WSN04A & 1704 & 1826 & 0.54 & 0.21 \\
\hline WSN04B & 1687 & 1826 & 0.67 & 0.23 \\
\hline WSN05A & 1745 & 1826 & 0.41 & 0.24 \\
\hline WSN05B & 1734 & 1826 & 0.46 & 0.29 \\
\hline WSN07A & 1700 & 1818 & 0.76 & 0.22 \\
\hline WSN07B & 1717 & 1822 & 0.55 & 0.21 \\
\hline WSN07C & 1699 & 1804 & 0.74 & 0.25 \\
\hline WSN08A & 1718 & 1827 & 0.62 & 0.18 \\
\hline WSN08C & 1713 & 1814 & 0.54 & 0.22 \\
\hline WSN09A & 1735 & 1824 & 0.65 & 0.16 \\
\hline WSN09B & 1721 & 1777 & 0.75 & 0.27 \\
\hline WSN10A & 1736 & 1810 & 0.75 & 0.16 \\
\hline WSN11A & 1749 & 1826 & 0.74 & 0.16 \\
\hline WSN11B & 1740 & 1826 & 0.69 & 0.21 \\
\hline WSN12B & 1715 & 1827 & 0.68 & 0.23 \\
\hline WSS02A & 1715 & 1824 & 0.50 & 0.20 \\
\hline WSS03B & 1722 & 1809 & 0.61 & 0.20 \\
\hline WSS04A & 1742 & 1826 & 0.56 & 0.22 \\
\hline WSS04B & 1729 & 1826 & 0.74 & 0.21 \\
\hline WSS05A & 1711 & 1826 & 0.55 & 0.17 \\
\hline WSS05B & 1706 & 1826 & 0.66 & 0.18 \\
\hline WSW02A & 1704 & 1824 & 0.54 & 0.16 \\
\hline WSW02B & 1672 & 1823 & 0.54 & 0.20 \\
\hline WSW03A & 1725 & 1825 & 0.64 & 0.25 \\
\hline WSW03B & 1713 & 1825 & 0.72 & 0.26 \\
\hline WSW04A & 1729 & 1826 & 0.66 & 0.22 \\
\hline WSW04B & 1691 & 1826 & 0.56 & 0.31 \\
\hline WSW05A & 1722 & 1825 & 0.60 & 0.16 \\
\hline WSW05B & 1723 & 1824 & 0.55 & 0.20 \\
\hline WSW05C & 1696 & 1825 & 0.65 & 0.19 \\
\hline WSW06B & 1737 & 1825 & 0.55 & 0.26 \\
\hline WSW07B & 1685 & 1802 & 0.57 & 0.24 \\
\hline WSW08B & 1716 & 1809 & 0.70 & 0.30 \\
\hline WSW10B & 1748 & 1822 & 0.36 & 0.25 \\
\hline WSW11B & 1701 & 1817 & 0.55 & 0.20 \\
\hline WSW12B & 1754 & 1827 & 0.64 & 0.17 \\
\hline \multicolumn{3}{|c|}{ Average } & 0.61 & 0.22 \\
\hline
\end{tabular}


Table 3. COFECHA Results: Correlation testing for oak cores from the John Sevier Cabin.

\begin{tabular}{|c|c|c|c|c|c|}
\hline \multirow[b]{2}{*}{ Series } & \multicolumn{5}{|c|}{ 40-Yr Segment Tested $*$} \\
\hline & $1720-1759$ & $1740-1779$ & $1760-1799$ & $1780-1819$ & $1800-1839$ \\
\hline JSE01A & 0.54 & 0.52 & 0.64 & 0.45 & \\
\hline JSE01B & $0.27 \mathrm{~B}$ & 0.51 & 0.66 & 0.50 & \\
\hline JSE01C & 0.75 & 0.78 & 0.73 & 0.56 & \\
\hline JSN03B & & 0.82 & 0.88 & 0.81 & \\
\hline JSN03C & 0.72 & 0.72 & 0.74 & 0.69 & 0.63 \\
\hline JSN03D & & 0.78 & 0.84 & 0.76 & \\
\hline JSN09C & & & $0.35 \mathrm{~A}$ & $0.26 \mathrm{~B}$ & \\
\hline JSN09D & & 0.54 & 0.55 & $0.26 \mathrm{~B}$ & $0.27 \mathrm{~B}$ \\
\hline JSS01A & 0.61 & 0.72 & 0.83 & 0.85 & \\
\hline JSS01B & & 0.45 & 0.79 & 0.66 & 0.50 \\
\hline JSS03A & & 0.74 & 0.70 & 0.73 & 0.64 \\
\hline JSS03B & 0.78 & 0.79 & 0.82 & 0.63 & 0.58 \\
\hline JSS03D & & 0.66 & 0.77 & 0.76 & 0.67 \\
\hline JSS03E & & 0.64 & 0.70 & 0.56 & \\
\hline JSW04B & & 0.77 & 0.81 & 0.85 & 0.86 \\
\hline JSW04C & & 0.82 & 0.86 & 0.83 & 0.79 \\
\hline Average & 0.61 & 0.68 & 0.73 & 0.63 & 0.62 \\
\hline
\end{tabular}

*An A or B flag indicates segments that had (A) correlations below the 0.37 benchmark ( $p>0.01)$ or (B) segments with correlations higher at an alternate position.

patterns were likely caused by local disturbances, such as windthrow or wildfire, that masked the stronger climate factor that causes the common patterns necessary for successful crossdating.

The final John Sevier RESIDUAL chronology (i.e. all autocorrelation removed within the chronology) had a highly significant correlation of $0.47(\mathrm{t}=5.71, \mathrm{p}<0.0001, \mathrm{n}=115$ years $)$ with the Norris Dam RESIDUAL oak chronology from 1720 to 1834 (Figure 4). The final Walker Springs RESIDUAL chronology had a lower but still statistically significant correlation of $0.34(\mathrm{t}=$ $4.49, \mathrm{p}<0.0001, \mathrm{n}=152$ years) with the Norris Dam RESIDUAL oak chronology from 1675 to 1826 (Figure 5). Together, the John Sevier oak chronology and the Walker Springs oak chronology displayed a very high correlation with each other of $0.56(\mathrm{t}=6.90, \mathrm{p}<0.0001, \mathrm{n}=107$ years $)$ (Figure 6), confirming the crossdating of the two chronologies.

Cores from two oak logs on the John Sevier cabin could not be dated with the Norris Dam reference chronology, but dated significantly against the Piney Creek Pocket Wilderness reference chronology, bringing the total number of dated $\operatorname{logs}$ to 8 (Table 5). Cores JSE07A and
JSN06A displayed statistically significant correlations with this chronology of $0.41(\mathrm{t}=4.56, \mathrm{p}<$ $0.0001, \mathrm{n}=105$ years $)$ and $0.46(\mathrm{t}=5.05, \mathrm{p}<$ $0.0001, \mathrm{n}=97$ years), respectively. Core JSE07A had an outermost ring of 1879. Core JSN06A had an outermost measured ring of 1868 , but had 11 rings (unmeasured) in the outer segment of the sapwood, which would make the outermost ring for the core 1879 as well. These two logs were clearly replacement logs taken from a structure created from trees that once grew more towards east-central Tennessee rather than eastern Tennessee based on the strength of correlations with the Piney Creek chronology. We observed that log JSE07 consisted of two sections, an oak section on its northern end and a pine section for the remainder.

\section{Cutting Dates}

The cutting dates for logs used in the John Sevier cabin clustered in the middle 1830s, although one $\log$ had a cutting date of 1830 (JSS01) (Table 5). Two logs (JSN03 and JSW04) had 1834 cutting dates while another $\log$ (JSS03) had a cutting date of 1835. Two logs had 
Table 4. COFECHA results: Correlation Testing for Oak Cores from the Walker Springs Cabin.

\begin{tabular}{|c|c|c|c|c|c|c|c|}
\hline \multirow[b]{2}{*}{ Series } & \multicolumn{7}{|c|}{ 40-Yr Segment Tested * } \\
\hline & $1680-1719$ & $1700-1739$ & $1720-1759$ & $1740-1779$ & $1760-1799$ & $1780-1819$ & $1800-1839$ \\
\hline WSE01A & & & 0.50 & 0.61 & 0.81 & 0.63 & 0.53 \\
\hline WSE01B & & 0.52 & 0.55 & 0.71 & 0.58 & 0.53 & \\
\hline WSE02A & & & 0.66 & 0.65 & 0.68 & 0.52 & 0.51 \\
\hline WSE02B & & & & 0.71 & 0.72 & 0.65 & \\
\hline WSE03A & & & 0.57 & 0.62 & 0.52 & 0.48 & 0.44 \\
\hline WSE03B & 0.68 & 0.65 & 0.71 & 0.65 & 0.75 & & \\
\hline WSE05A & & & 0.80 & 0.86 & 0.67 & 0.63 & \\
\hline WSE05B & & 0.63 & 0.55 & 0.64 & 0.70 & 0.66 & 0.68 \\
\hline WSE11A & 0.66 & 0.67 & 0.65 & 0.57 & 0.58 & 0.61 & \\
\hline WSN02A & & 0.73 & 0.67 & 0.58 & 0.61 & 0.62 & \\
\hline WSN03A & & & & 0.71 & 0.67 & 0.60 & 0.58 \\
\hline WSN03B & & & & & 0.75 & 0.75 & 0.76 \\
\hline WSN04A & & 0.53 & 0.55 & 0.65 & 0.61 & 0.48 & 0.46 \\
\hline WSN04B & 0.86 & 0.80 & 0.65 & 0.75 & 0.56 & 0.45 & 0.47 \\
\hline WSN05A & & & & $0.17 \mathrm{~B}$ & 0.51 & 0.62 & 0.61 \\
\hline WSN05B & & & 0.37 & 0.37 & 0.60 & 0.52 & 0.56 \\
\hline WSN07A & & 0.83 & 0.82 & 0.75 & 0.79 & 0.70 & \\
\hline WSN07B & & 0.55 & 0.39 & 0.58 & 0.58 & 0.42 & 0.48 \\
\hline WSN07C & 0.80 & 0.80 & 0.85 & 0.75 & 0.66 & 0.66 & \\
\hline WSN08A & & 0.48 & 0.55 & 0.77 & 0.82 & 0.64 & 0.63 \\
\hline WSN08C & & $0.26 \mathrm{~B}$ & 0.45 & 0.84 & 0.82 & 0.69 & \\
\hline WSN09A & & & 0.75 & 0.81 & 0.75 & 0.52 & 0.54 \\
\hline WSN09B & & & 0.76 & 0.81 & & & \\
\hline WSN10A & & & 0.81 & 0.77 & 0.82 & 0.73 & \\
\hline WSN11A & & & & 0.81 & 0.84 & 0.68 & 0.66 \\
\hline WSN11B & & & & 0.76 & 0.85 & 0.62 & 0.57 \\
\hline WSN12B & & 0.59 & 0.62 & 0.75 & 0.86 & 0.74 & 0.68 \\
\hline WSS02A & & $0.29 \mathrm{~A}$ & 0.41 & 0.77 & 0.69 & 0.49 & 0.48 \\
\hline WSS03B & & & 0.65 & 0.63 & 0.62 & 0.56 & \\
\hline WSS04A & & & & 0.66 & 0.57 & 0.51 & 0.42 \\
\hline WSS04B & & & 0.73 & 0.76 & 0.87 & 0.80 & 0.74 \\
\hline WSS05A & & 0.52 & 0.67 & 0.73 & 0.70 & 0.39 & $0.35 \mathrm{~A}$ \\
\hline WSS05B & & 0.64 & 0.73 & 0.80 & 0.75 & 0.52 & 0.47 \\
\hline WSW02A & & 0.65 & 0.75 & 0.63 & 0.53 & 0.41 & $0.34 \mathrm{~A}$ \\
\hline WSW02B & 0.41 & 0.76 & 0.78 & 0.74 & 0.61 & 0.45 & 0.49 \\
\hline WSW03A & & & 0.50 & 0.64 & 0.78 & 0.72 & 0.68 \\
\hline WSW03B & & 0.77 & 0.70 & 0.74 & 0.71 & 0.68 & 0.66 \\
\hline WSW04A & & & 0.64 & 0.72 & 0.77 & 0.70 & 0.63 \\
\hline WSW04B & $0.24 \mathrm{~B}$ & $0.36 \mathrm{~A}$ & 0.64 & 0.77 & 0.76 & 0.62 & 0.65 \\
\hline WSW05A & & & 0.66 & 0.49 & 0.56 & 0.72 & 0.64 \\
\hline WSW05B & & & 0.61 & 0.77 & 0.79 & 0.55 & 0.45 \\
\hline WSW05C & 0.70 & 0.71 & 0.81 & 0.78 & 0.70 & 0.54 & 0.40 \\
\hline WSW06B & & & 0.49 & 0.53 & 0.59 & 0.66 & 0.57 \\
\hline WSW07B & 0.52 & 0.64 & 0.71 & 0.83 & 0.53 & 0.46 & \\
\hline WSW08B & & 0.73 & 0.65 & 0.69 & 0.79 & 0.67 & \\
\hline WSW10B & & & & 0.37 & 0.40 & 0.42 & 0.44 \\
\hline WSW11B & & 0.50 & 0.61 & 0.60 & 0.61 & 0.46 & \\
\hline WSW12B & & & & 0.77 & 0.81 & 0.58 & 0.58 \\
\hline Average & 0.61 & 0.60 & 0.64 & 0.68 & 0.68 & 0.58 & 0.55 \\
\hline
\end{tabular}

*An A or B flag indicates segments that had (A) correlations below the 0.37 benchmark (p $>0.01)$ or (B) segments with correlations higher at an alternate position. 


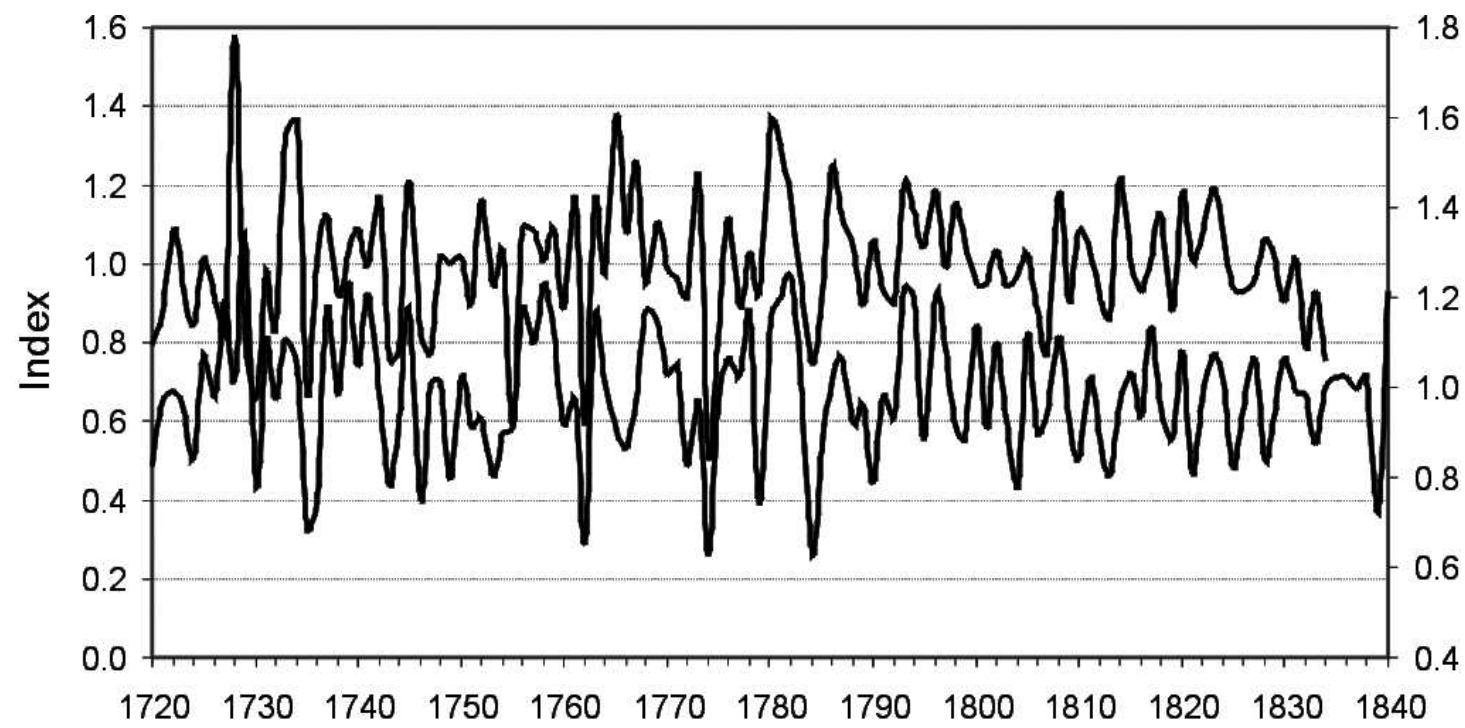

Figure 4. Crossdating between the John Sevier cabin RESIDUAL index chronology (upper) with the Norris Dam State Park RESIDUAL index chronology (bottom) from 1720 to 1834 ( $\mathrm{r}=0.47, \mathrm{t}=5.71, \mathrm{p}<0.0001, \mathrm{n}=115$ years). The scales of the two $\mathrm{y}$ axes are slightly different to visually highlight the crossdating.

outermost dates of 1832 (JSE01 and JSN09) based on ring counts on the separated core sections in the sapwood, but these dates nonetheless support tree harvesting in the middle 1830s. The clustering of outermost dates on these five oak logs suggests a construction of the cabin in the period 1834
1835. Ideally, we would have preferred a minimum of $10 \operatorname{logs}$ with a clear clustering of outermost dates in a one to two-year period before inferring a possible year of construction, but the degraded condition of the logs in this cabin hindered this assessment.

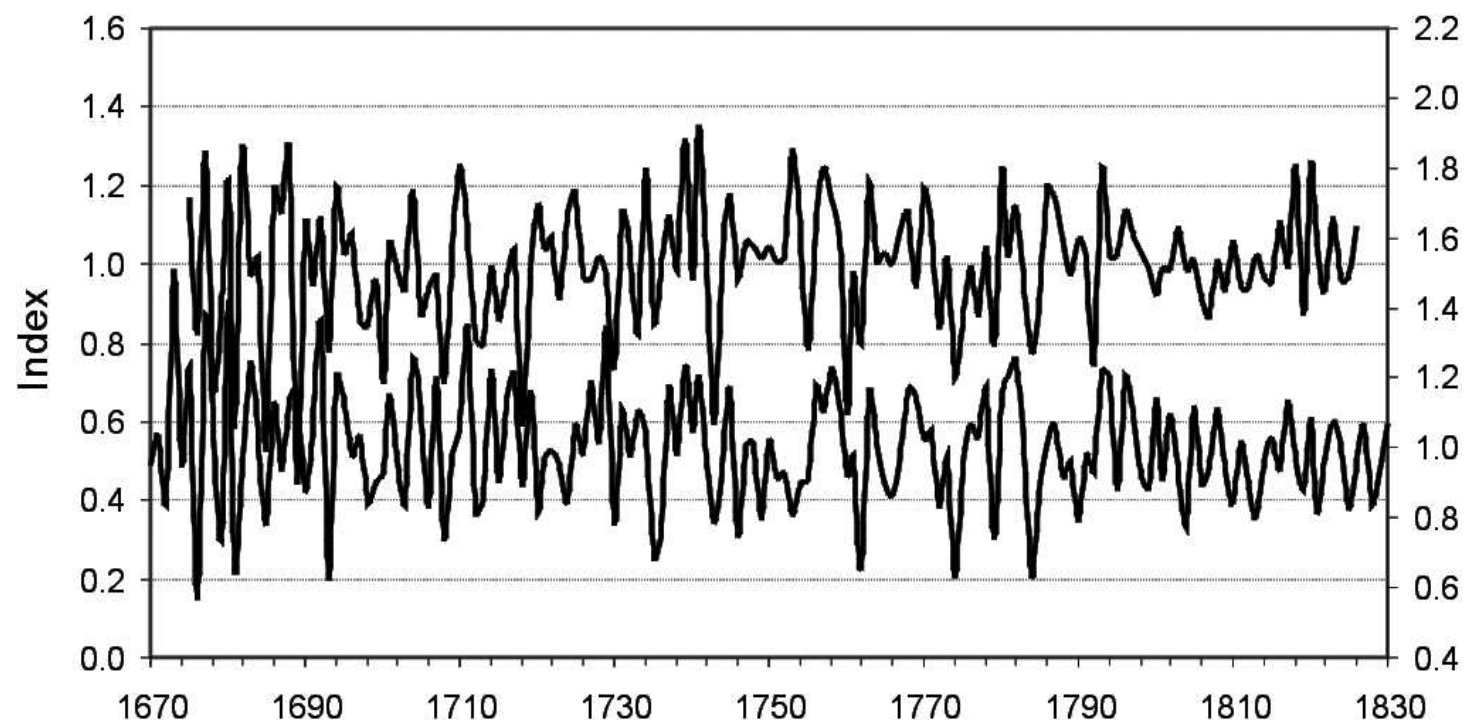

Figure 5. Crossdating between the Walker Springs cabin RESIDUAL index chronology (upper) with the Norris Dam State Park RESIDUAL index chronology (bottom) from 1675 to $1826(\mathrm{r}=0.34, \mathrm{t}=4.49, \mathrm{p}<0.0001, \mathrm{n}=152$ years). The scales of the two $\mathrm{y}$ axes are slightly different to visually highlight the crossdating. 


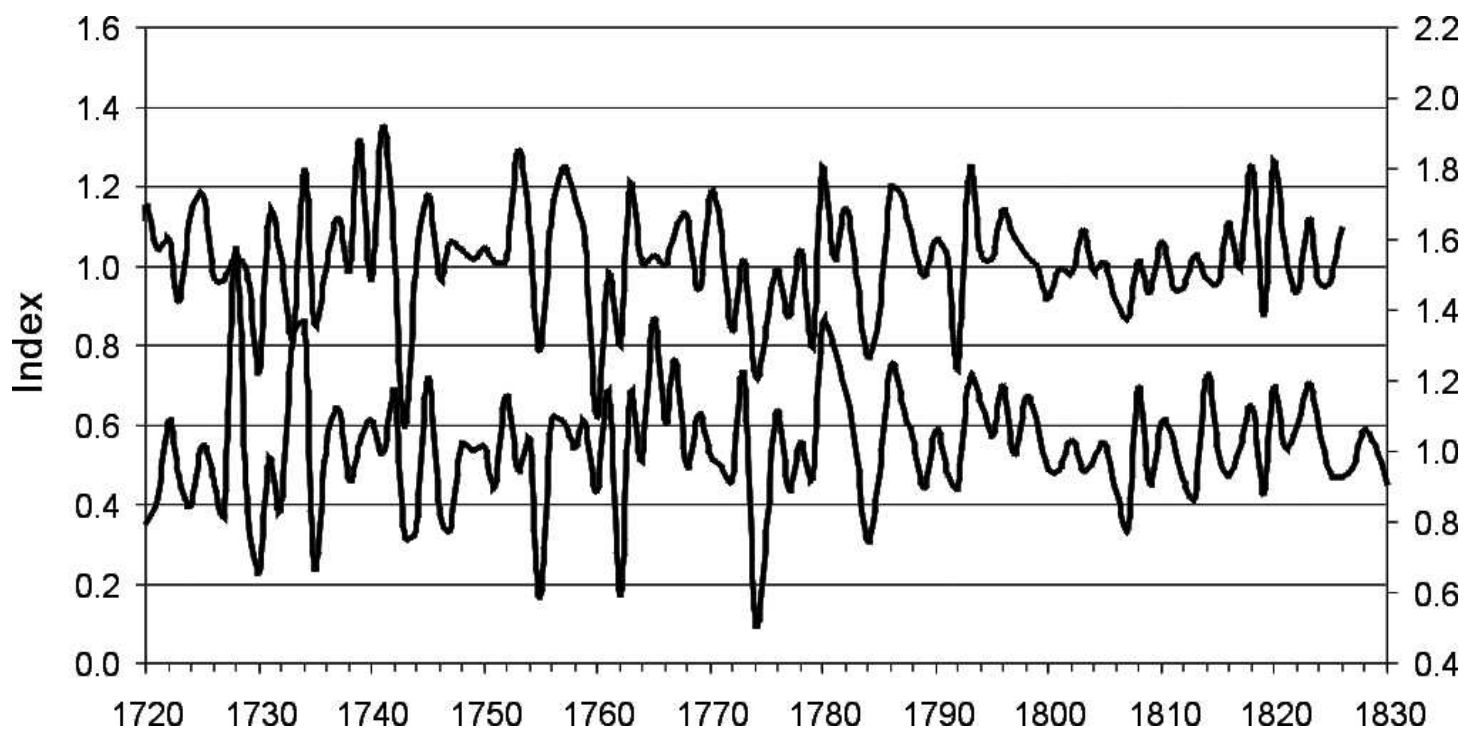

Figure 6. Crossdating between the Walker Springs cabin RESIDUAL index chronology (upper) with the John Sevier cabin RESIDUAL index chronology (bottom) from 1720 to $1826(\mathrm{r}=0.56, \mathrm{t}=6.90, \mathrm{p}<0.0001, \mathrm{n}=107$ years). The scales of the two $\mathrm{y}$ axes are slightly different to visually highlight the crossdating.

The cutting dates for logs used in the Walker Springs cabin (Table 6) provide a stark contrast. Our success in crossdating the rings in these logs and the clear clustering of outermost ring dates likely was the result of the protective covering of clapboard siding installed on the house for much of its existence. Virtually all $\operatorname{logs}(29)$ support cutting dates in the period 1827-1828, making this cabin one of the most reliably dated historic structures in the Southeastern U.S. Many logs (e.g. WSE03, WSN03, WSN04, WSN05, WSN10, WSW04, and WSW08) had an outermost ring of 1827 that had only earlywood vessels present, suggesting that the trees were harvested soon after the trees had broken dormancy in the spring of 1827. Other logs (e.g. WSE05, WSN11, WSN12,

Table 5. Cutting Dates for Oak and Pine Logs from the Governor John Sevier Cabin.

\begin{tabular}{|c|c|c|c|c|}
\hline $\log$ & $\begin{array}{l}\text { Outer } \\
\text { Ring }\end{array}$ & $\begin{array}{l}\text { Ring } \\
\text { Type }^{1}\end{array}$ & Comments & Inferred Period for Cutting \\
\hline JSE01 & 1832 & $\mathrm{r}++$ & Crossdated to 1813 , then 19 rings in outer section added & Tree likely cut sometime in 1830 s \\
\hline JSE07 & 1879 & $\mathrm{r}$ & $\begin{array}{l}\text { Dated against Piney Creek }=\text { replacement log; } 1879 \text { ring } \\
\text { appears complete }\end{array}$ & $\begin{array}{l}\text { Tree cut anytime from late summer } \\
1879 \text { to spring } 1880\end{array}$ \\
\hline JSN03 & 1834 & $\mathrm{r}$ & Crossdated to $1833 ; 1834$ earlywood present & Tree cut in spring 1834 \\
\hline JSN06 & 1879 & $\mathrm{r}$ & $\begin{array}{l}\text { Dated against Piney Creek }=\text { replacement log; } 1879 \text { ring } \\
\text { appears complete }\end{array}$ & $\begin{array}{l}\text { Tree cut anytime from late summer } \\
1879 \text { to spring } 1880\end{array}$ \\
\hline JSN09 & 1832 & $\mathrm{r}++$ & Crossdated to 1817 , then 15 rings in outer section added & Tree likely cut sometime in $1830 \mathrm{~s}$ \\
\hline JSS01 & 1830 & $\mathrm{r}$ & Crossdated to 1829 , but 1830 ring appears complete & $\begin{array}{l}\text { Tree cut anytime from summer } 1830 \text { to } \\
\text { spring } 1831\end{array}$ \\
\hline $\mathrm{JSS} 03$ & 1835 & $\mathrm{r}$ & Crossdated to 1834 , but 1835 ring appears complete & $\begin{array}{l}\text { Tree cut anytime from summer } 1835 \text { to } \\
\text { spring } 1836\end{array}$ \\
\hline JSW04 & 1834 & $\mathrm{r}$ & Crossdated to 1833 , but 1834 ring appears complete & $\begin{array}{l}\text { Tree cut anytime from summer } 1834 \text { to } \\
\text { spring } 1835\end{array}$ \\
\hline
\end{tabular}

${ }^{1} \mathrm{r}$ : outermost ring is continuous and intact around a smooth surface, but no bark is present (considered a cutting date);

$\mathrm{v}$ : the date is within a few years of the cutting date, based on presence of sapwood (supports a later cutting date);

++: a ring count was necessary for the outermost section on a core with two sections separated by decay. 


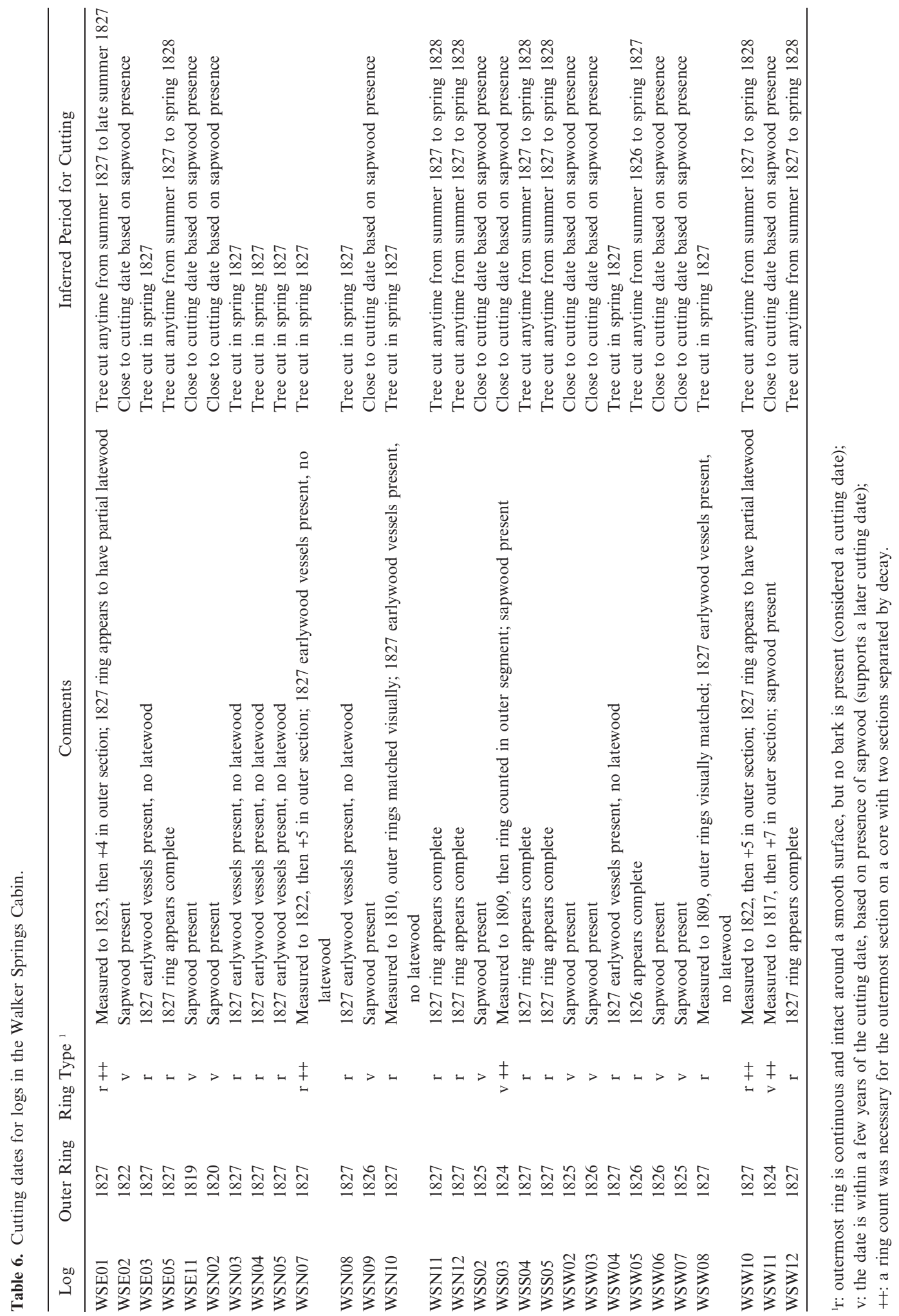


WSS04, WSS05, and WSW12) had more complete latewood for the year 1827, suggesting that these trees were harvested later in the growing season, perhaps in late summer or fall of 1827 . However, these rings may have formed completely by the time the trees were cut, suggesting harvesting any time from fall of 1827 to late winter 1828 .

\section{Discussion}

The quality of crossdating and the statistics of the resulting tree-ring chronologies from both cabins were comparable to previously created oak reference chronologies in the region. The high inter-series correlations between ring patterns from the John Sevier cabin, the Walker Springs cabin, and the Norris Dam living trees (as well as the trees used to create the Piney Creek reference chronology) demonstrate the regional climatic signal for eastern Tennessee common in all data sets. Ideally, we would have liked additional trees to strengthen the sample size in the John Sevier cabin, but we nonetheless feel strongly that the statistically significant correlation calculated between the chronology from this cabin and the Norris Dam chronology indicates that the John Sevier cabin is correctly and convincingly placed in time. Such a high correlation would not have occurred had the individual ring series not been correctly crossdated. Marker rings such as 1755, 1762,1774 , and 1813 are all clearly present in both the John Sevier cabin cores and the Norris Dam reference chronology. In some years, the two chronologies clearly did not correspond (such as the years 1732, 1736, 1753, and 1807), but these discrepancies are likely because of either differences in local climate patterns or influences of local disturbances and do not override the overall regional climate signal shared between these two chronologies.

Asynchrony could have occurred because trees may have been affected by stand-specific local disturbances common in eastern U.S. forests, especially gap formation caused by windthrow or expected tree mortality (Runkle 1982; Orwig and Abrams 1995; Frelich 2002; Cseke 2003). The tree rings in such segments often display lower correlations because the segment had a weaker relationship to climate during the period of influence by these disturbances. Still, we point out that the series or portions of series with lower correlations still always had positive correlations (rather than near zero or negative correlations) compared to segments from other series, suggesting that some signal was present despite the added noise.

As expected after our initial visual inspection, we were unable to conclusively date some of the cores collected from oak logs in the John Sevier cabin. In general, the logs (both oak and pine) in the John Sevier cabin are in poor condition, and the cores taken from this cabin were also in poor condition. On most cores, the sapwood was heavily decayed causing a gap between the sapwood and heartwood, although occasionally we found that we had all the rings despite this gap. Sapwood is especially vulnerable to insect infestation (resulting in the ubiquitous beetle galleries) and decay caused by moisture, in addition to its susceptibility to removal during the log hewing process (Baillie 1982; Mann 2002). Occasionally, cores were too short because of internal decay, causing too few rings for accurate crossdating. In contrast, the logs in the Walker Springs cabin were all in excellent condition, likely because the structure was covered for most of its existence by protective clapboard siding when it was located in west Knoxville, Tennessee (Faulkner 1991). As a result, we were able to develop a new high quality, well replicated, reference tree-ring chronology for eastern Tennessee from this one structure. The cutting period of 1827 to 1828 for the Walker Springs cabin corroborates the findings from an earlier study based on architectural dating that indicated the cabin "could have been built several years before 1830" (Faulkner 1991).

In the John Sevier cabin, the logs with series that could be crossdated had smooth intact outer surfaces with outermost ring dates ranging from the early to mid-1830s. Two of these logs (as well as seven in the Walker Springs cabin) had outermost sections of cores that had separated from the main portion of the core. The rings in these separated sections were not measured but could be visually compared to rings in the sapwood on complete cores to visually match the 
ring patterns and come up with an estimated outermost ring date. Two logs that we sampled on the John Sevier cabin were obvious replacement logs from another structure as these had much later outermost dates (1879) than the other six logs.

The John Sevier cabin was likely completed shortly after the last of the trees was felled, putting the time of completion somewhere between the summer of 1835 to the early spring of 1836 . These cutting dates make the inhabitance of this cabin by Governor John Sevier impossible because these logs were felled well after his death in 1815. This would place the time of construction during the period of ownership (1818-1847) by James Dardis, but historians are unclear who actually lived at Marble Springs during this interval (Faberson 2005). In 1818, the Sevier heirs sold the property to James Dardis who continued to own the land until 1847, when the property was bought by George Kirby (Barber 2005). It is unlikely that Dardis ever lived at Marble Springs because he was a wealthy attorney and the property was simply one of his investments. Instead, the property was likely occupied by tenants at this time, namely the Kirby family (Faberson 2005). George Kirby is found on the 1840 census living in the Marble Springs area. Because Kirby had a son who was then 7 years old, he must have been married by at least 1832, placing him in time there to harvest the logs for what is now known as the John Sevier cabin. We believe that Kirby probably built the cabin shortly before or when he got married, not uncommon in those days. Interestingly, few historical artifacts that dated between 1820 and the 1840s-1850s were uncovered in previous archaeological investigations. It is very possible that no one lived permanently at the Marble Springs Historic Site until after 1830 when Dardis moved to Winchester, Tennessee, and George Kirby began living there as a caretaker. Kirby eventually purchased part of the original Sevier tract when Dardis died in 1847.

\section{ACKNOWLEDGMENTS}

We are indebted to the Tennessee Historical Commission that continues to recognize the value of dendroarchaeological dating and interpretation of historic sites in Tennessee. Steve Rogers of the THC especially should be commended for his logistical support and encouragement throughout the project. We thank Tracy Caskey, the former Director of the Marble Springs Historic Site, and David Daily, the current Site Manager, for help in allowing us unfettered access to the two historic $\log$ houses. We were greatly aided by numerous students of the Department of Geography who graciously took time off from their own busy schedules to help us collect the core samples: Christopher Underwood, Saskia van de Gevel, Lisa LaForest, Georgina DeWeese, Tim Green, Brian Watson, and Philip White. Dr. John Rehder of the Department of Geography accompanied us on several trips to Marble Springs and provided valuable input on the history of the two log structures on the farmstead.

\section{REFERENCES CITED}

Baillie, M. G. L., 1982. Tree-Ring Dating and Archaeology. The University of Chicago Press, Chicago.

, 1995. A Slice Through Time: Dendrochronology and Precision Dating. B.T. Batsford, London.

Bannister, B., 1962. The interpretation of tree-ring dates. American Antiquity 27:508-514.

Barber, J. L., 2005. Historical Background: John Sevier at Marble Springs. In Archaeological Excavations at Marble Springs: Summer, 2003, edited by T. A. Faberson, and C. H. Faulkner, pp. 4-7. Department of Anthropology, University of Tennessee, Knoxville.

Bortolot, Z. J., C. A. Copenheaver, R. L. Longe, and J. A. N. Van Aardt, 2001. Development of a white oak chronology using live trees and a post-Civil War cabin in south-central Virginia. Tree-Ring Research 57:197-203.

Bowers, L. J., and D. L. Grashot, 1976. Results of the first Hermitage dendrochronological study. In An Archaeological and Historical Assessment of the First Hermitage, edited by S. D. Smith, pp. 271-281. Division of Archaeology, Tennessee Department of Conservation, and The Ladies Hermitage Association, Nashville, Tennessee.

Cseke, J. J., 2003. A Dendroecological Approach for Dating Individual Small-scale Canopy Disturbance Events, Great Smoky Mountains National Park, Tennessee, USA, M.S. thesis, University of Tennessee, Knoxville.

Dean, J. S., 1978. Tree-ring dating in archaeology. In Miscellaneous Collected Papers 19-24, edited by J. D. Jennings, pp. 129-163. University of Utah Anthropological Papers 99.

DeWitt, E., and M. Ames, 1978. Tree Ring Chronologies of Eastern North America. Laboratory of Tree-Ring Research, 
University of Arizona, Tucson. Chronology Series IV, Volume 1.

Duvick, D. N., 1981. Norris Dam State Park, Tennessee, White Oak Chronology. IGBP Pages/World Data Center for Paleoclimatology Data Contribution Series \# 03613-08405. NOAA/NCDC Paleoclimatology Program, Asheville, North Carolina, USA.

, 1983. Piney Creek Pocket Wilderness, Tennessee, White Oak Chronology. IGBP Pages/World Data Center for Paleoclimatology Data Contribution Series \# 03542-08453. NOAA/NCDC Paleoclimatology Program, Asheville, North Carolina, USA.

Faberson, T. A., 2005. In the Shadow of Greatness: The Archaeology of Capitalism, Agriculture, and the Informal Economy at Marble Springs, Knox County, Tennessee, 1847 1932, Ph.D. dissertation, The University of Tennessee, Knoxville.

Faberson, T. A., and C. H. Faulkner, Editors, 2005. Archaeological Excavations at Marble Springs: Summer, 2003. Department of Anthropology, University of Tennessee, Knoxville.

Faulkner, C. H., 1991. The walls can speak: A history of the William Walker house. Tennessee Ancestors 7(1):42-48.

Frelich, L. E., 2002. Forest Dynamics and Disturbance Regimes: Studies from Temperate Evergreen-Deciduous Forests. Cambridge University Press, New York.

Fritts, H. C., 1976. Tree Rings and Climate. Academic Press, New York.

Grissino-Mayer, H. D., 2001. Evaluating crossdating accuracy: A manual and tutorial for the computer program COFECHA. Tree-Ring Research 57:205-221.

Grissino-Mayer, H. D., and S. L. van de Gevel, 2007. Tell-tale trees: The historical dendroarchaeology of log structures at Rocky Mount, Piney Flats, Tennessee. Historical Archaeology 41:30-47.

Holmes, R. L., 1983. Computer-assisted quality control in treering dating and measurement. Tree-Ring Bulletin 43:69-75.

Lewis, D. B., W. L. Kocis, H. D. Grissino-Mayer, and E. R. Cook, 2006. Dendrochronological dating of eastern red cedar (Juniperus virginiana L.) logs from Alfred's Cabin, The Hermitage, Home of President Andrew Jackson. Final
Report, The Ladies' Hermitage Association and the Tennessee Historical Commission, Hermitage, Tennessee.

Mann, D. F., 2002. The Dendroarchaeology of the Swaggerty Blockhouse, Cocke County, Tennessee, M.S. thesis, University of Tennessee, Knoxville.

Miller, M., 2000. A History of General John Sevier and his Last Known Home: Marble Springs. Department of Anthropology, University of Tennessee, Knoxville.

Nash, S. E., 1999. Time, Trees, and Prehistory: Tree-Ring Dating and the Development of North American Archaeology, 1914-1950. University of Utah Press, Salt Lake City.

Orwig, D. A., and M. D. Abrams, 1995. Dendroecological and ecophysiological analysis of gap environments in mixed-oak understorys of northern Virginia. Functional Ecology 9: 799-806.

Phipps, R. L., 1985. Collecting, preparing, crossdating, and measuring tree increment cores. U.S. Geological Survey Water Resources Investigations Report, 85-4148.

Ramsey, J. G. M., 1853. The Annals of Tennessee. Walker and Jones, Charleston, South Carolina.

Reding, W. M., 2002. Assessment of Spatial and Temporal Patterns of Log Structures in East Tennessee, M.S. thesis, Department of Geography, University of Tennessee, Knoxville.

Runkle, J. R., 1982. Patterns of disturbance in some old-growth mesic forests of eastern North America. Ecology 63:15331546.

Sevier, J., 1790-1815. Journal of General John Sevier. Special Collections Library, University of Tennessee, Knoxville, and Tennessee History Magazine, Volumes 5 and 6.

Stahle, D. W., 1979. Tree-dating of historical buildings in Arkansas. Tree-Ring Bulletin 39:1-28.

Wight, G. D., and H. D. Grissino-Mayer, 2004. Dendrochronological dating of an Antebellum Period house, Forsyth County, Georgia, U.S.A. Tree-Ring Research 60:91-99.

Yamaguchi, D. K., 1991. A simple method for cross-dating increment cores from living trees. Canadian Journal of Forest Research 21:414-416.

Received 20 April 2007; accepted 12 August 2008. 